\title{
Changes in the Occurrence of Late Spring Frost in Poland
}

\author{
Dariusz Graczyk * (D) and Małgorzata Szwed 1 \\ Institute for Agricultural and Forest Environment, Polish Academy of Sciences, Bukowska 19, \\ 60-809 Poznan, Poland; mszwed@man.poznan.pl \\ * Correspondence: darekgraczyk@wp.pl
}

Received: 30 September 2020; Accepted: 19 November 2020; Published: 22 November 2020

\begin{abstract}
Trends in the appearance of the last spring frost for three thresholds of minimum daily air temperature at the height of $2 \mathrm{~m}$ and near the ground were examined for six meteorological stations located in two agricultural regions in Poland. For most time series, the last spring frost, calculated as a consecutive day of the year, showed a statistically significant trend indicating its earlier appearance from 1.6 to about 3.5 days per decade. The date of the last spring frost was also calculated in relation to the ongoing growing season. In this case, few statistically significant changes in the dates of the last frosts were found. The probability of the last spring frost on a specific day of the calendar year and the day of the growing season was also examined for two periods: 1961-1990 and 1991-2020. For low probability levels corresponding to the early dates of the last spring frost, the last frost usually occurred much earlier (6-14 days) in 1991-2020. With the probability levels of $80-90 \%$ describing the late occurrence of the last frost with a frequency of once every 5-10 years, at some stations, the last spring frosts occurred at a similar time for both periods.
\end{abstract}

Keywords: late spring frost; trend; Poland

\section{Introduction}

A frost occurs when the minimum air temperature (measured at the height of $2 \mathrm{~m}$ ) drops below $0{ }^{\circ} \mathrm{C}$, even if the average daily air temperature is still positive.

Most often, such a situation occurs at night or in the morning and is caused by the influx of cold (often the Arctic) air through a cloudless sky or as a result of cooling the air layer near the ground as a consequence of the heat radiating from the ground into the atmosphere. This research study is dealing with late spring frosts, i.e., frosts that already occur during the growing season. These frosts are one of the most important factors that can cause significant damage to crops when they occur during the development of the plants, and thus they can result in significant losses in the production of fruit, horticultural and field plants, and in extreme cases, even destroy the entire crop.

The nature of frost damage depends upon the plant development stage at which the frost occurs. In general, at the beginning of vegetation, the frost resistance of plants is very low, while the most critical moment is the flowering phase for some plants or the beginning of leaf formation for others. Hence, late frosts that can damage flower buds, flowers and fruit buds are particularly dangerous. In addition, the minimum temperature, and thus the frost, is characterized by great spatial variability, especially in a diversified area. The severity of frost and hence the extent of subsequent damage depends on the location of the crop and may be different for the same plant.

The early start of vegetation in areas exposed to late spring frosts significantly increases the probability of large yield losses. In Poland, there are areas with varying degrees of frost risk. The longer the period between the occurrence of an average daily air temperature higher than $5^{\circ} \mathrm{C}$ and the day when the probability of frost drops to $5 \%$, the greater the potential threat to plants. For Wielkopolska, 
the main agricultural area in the country, this period lasts up to 45 days [1] and is one of the longest in Poland. Characteristics of frosts on a national or regional scale can be found in numerous studies, e.g., [2-7], etc.

During the twentieth century, in large parts of the world's land surface, the average temperature has increased, wherein minimum temperatures were generally observed to increase more than maximum temperatures [8,9]. However, in Central and Western Europe in recent decades, the opposite trend was observed, and maximum temperatures have been increasing more than minimum temperatures [10]. The frequency and intensity of frosts have decreased with global warming in temperate latitude. The vegetation onset in spring has also advanced by almost two weeks during the period 1982-2011 in Western Europe [11]. Increased temperatures, associated with earlier last spring frost and delayed autumn frost dates, have been reported for some regions of Europe [12-14]. Climate projections indicate larger frost risk after the onset of spring plant growth in a future climate [15].

With such trends observed in Europe, one would expect that as the dates of the last spring frosts accelerate, the risk of yield losses caused by frosts would also decrease. This paper tries to answer the following questions: (i) Does the shift of the last frost occur in Poland? (ii) Is this shift of the frosts date sufficient for the plants to develop enough to stop being prone to frost? (iii) What does this shift look like in relation to the growing season, which is also accelerating?

The research was carried out on the basis of the measurement data of the daily minimum air temperature at the height of $2 \mathrm{~m}$ and near the ground for six stations located in the agricultural regions of the country, in the Lowland Wielkopolska and the highland belt in the southeast of Poland.

Due to the large spatial variability of the minimum temperature, the obtained results largely depend on the location of the measuring station. Therefore, it is difficult to extrapolate them to larger areas. However, the definition of the last spring frost date defined in this paper both during the calendar year and in relation to the growing season should contribute to the correct interpretation of the results.

\section{Data and Methods}

The present study used time series of the minimum daily air temperature at the height of $2 \mathrm{~m}$ (air frosts) and $0.05 \mathrm{~m}$ (ground frosts) above ground level, and time series of the average daily air temperature at the height of $2 \mathrm{~m}$. Six meteorological stations located in two agricultural regions in Poland were selected for the analysis. The location of the meteorological stations is shown in Figure 1. The selection of stations was limited by the number of complete time series of temperature near the ground. The data used covered the period of 1961-2020 for both heights. Only in the case of 2 stations, i.e., Wielichowo and Kielce, the temperature time series near the ground began in 1966. The data used in the research was collected and made available by the Polish Institute of Meteorology and Water Management-National Research Institute (IMGW-PIB). They were downloaded from Public Data Repository, https://dane.imgw.pl/, last accessed on 10 August 2020.

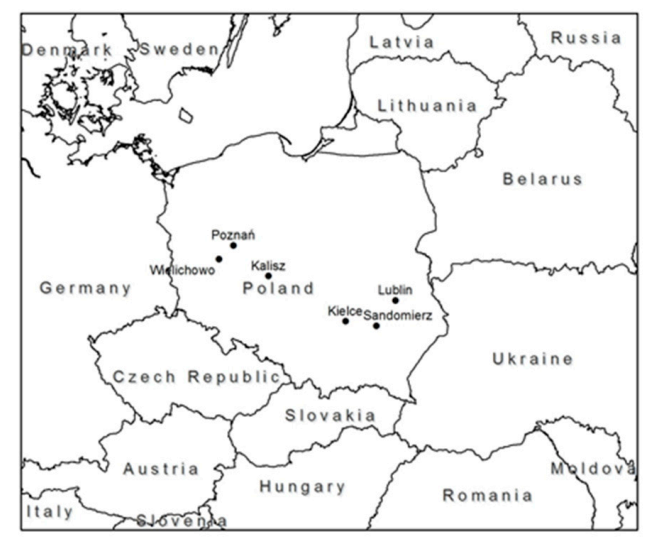

Figure 1. Location of the meteorological stations used in the study. 
From the time series of the minimum daily air temperature at the height of $2 \mathrm{~m}$, the time series of the last spring frost dates for three temperature thresholds were created, namely: Tmin $<0{ }^{\circ} \mathrm{C}$, Tmin $<-1{ }^{\circ} \mathrm{C}$ and $\mathrm{Tmin}<-2{ }^{\circ} \mathrm{C}$. Slightly lower temperature thresholds were assumed for frost near the ground: Tmin $<0{ }^{\circ} \mathrm{C}$, Tmin $<-2{ }^{\circ} \mathrm{C}$, and $\operatorname{Tmin}<-4{ }^{\circ} \mathrm{C}$, respectively. The selected thresholds refer to the divisions into the severity of frost used by other authors. Different studies often use other temperature thresholds, e.g., in WMO publication, there is mild frost- $\mathrm{Tmin}<0{ }^{\circ} \mathrm{C}$, moderate frost-Tmin $<-1.1^{\circ} \mathrm{C}$ and severe frost-Tmin $<-2.2^{\circ} \mathrm{C}$ [16], while Dragańska et al. [17] force some other values. The thresholds adopted in this research study are adequate for the analyzed areas and ensure that they can be a good basis for deriving reliable probability levels (see below). Finally, 72 time series of the last spring frost date were obtained. This term is defined as (i) the number of a consecutive day in the calendar year in which the last frost for a given temperature threshold appeared, but no later than 30 June; and (ii) the number of a consecutive day of the growing season in which the last frost for the specified temperature threshold appeared, but no later than 30 June.

In Poland, the most frequently used methods of determining the beginning of the growing season are those related to the determination of the dates when the average daily air temperature exceeded the threshold of $5^{\circ} \mathrm{C}[18,19]$. For the beginning of the growing season, the method proposed by [20] was applied, i.e., as the first span of at least 6 days with daily mean temperature Tavg $>5^{\circ} \mathrm{C}$. In Poland, it sometimes happens that this condition is already met in January, and then there are periods with strong temperature decreases, which certainly interrupt the growing season. Therefore, for the purposes of this research study, the second condition was introduced, stating that the growing season cannot be interrupted for a period of 6 days or longer with the average daily air temperature Tavg $<5^{\circ} \mathrm{C}$.

For every year, the last spring frost date was defined both: (i) as a number of days in the calendar year and (ii) as a number of the day during the growing season. Moreover, then the time series of the last frost dates were used for trend detection employing the Mann-Kendall test. The threshold of statistical significance was a level of $\geq 95 \%$ ( $<0.05$ according to another convention). The change per time unit (decade) was calculated using linear regression. All calculations were made with the Hydrospect 2.0 software [21].

Additionally, the time series of the day of the last spring frost occurrence were divided into two sub-periods, 1961-1990 and 1991-2020, and using R package [22], the probability curves of the last spring frost date ranging from 10 to $95 \%$ were adjusted. From the 17 methods offered by the package for probability curve fitting, the best 3 methods were selected for each series and the mean was drawn from them. Figure 2 shows the example of a probability curve for the last spring frost to occur on a specific day of the year. The presented diagram can be interpreted for the point marked with a black line (90\% and 120 days) as (i) The 120th day in a year is with $90 \%$ probability the date of the last spring frost for this time series; (ii) There is a $10 \%$ probability that the last spring frost for this station will occur after the 120th day of the year; and (iii) The last spring frost after the 120th day of the year may be repeated once in 10 years.

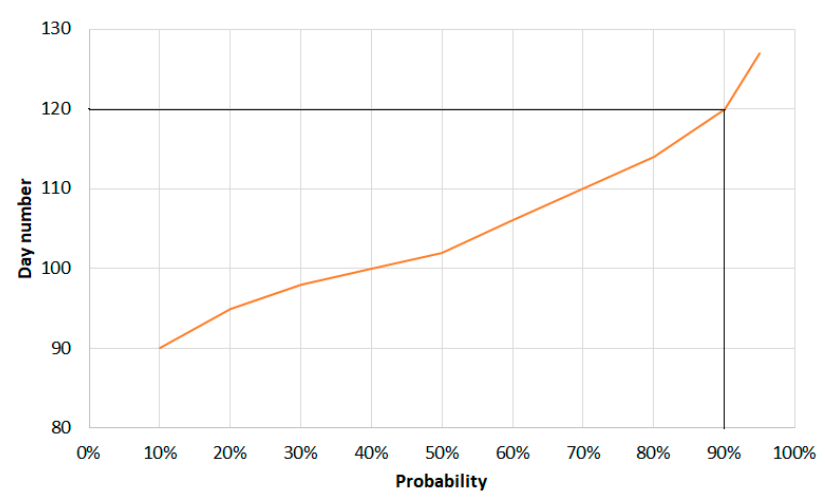

Figure 2. Probability curve for the last spring frost occurring on a specific day of the year. 


\section{Results}

\subsection{Changes in the Last Spring Frost Occurrence Date}

\subsubsection{Air Frosts}

The analysis of trends in the occurrence date of the last spring frost understood as the number of consecutive days in a year was carried out. For frosts with a minimum temperature below $0{ }^{\circ} \mathrm{C}$ measured at $2 \mathrm{~m}$ levels, a statistically significant trend occurred at four out of six analyzed stations, and in the years 1961-2020, it ranged from -1.6 days to -3.5 days per decade (Table 1). Similar results were obtained for the minimum temperature threshold of $-1{ }^{\circ} \mathrm{C}$ for which the Mann-Kendall test indicated the existence of a statistically significant trend at four out of six analyzed stations. For an even lower temperature threshold, $-2{ }^{\circ} \mathrm{C}$, a statistically significant acceleration of the last spring frosts date took place at three stations. In total, a statistically significant trend was detected in 11 of the 18 time series.

Table 1. Trend characteristics of the last spring air frosts date in relation to the calendar year (1961-2020).

\begin{tabular}{|c|c|c|c|c|}
\hline \multirow{2}{*}{ Station } & \multicolumn{2}{|c|}{ Linear Regression } & \multicolumn{2}{|c|}{ Mann-Kendall's Test } \\
\hline & $\begin{array}{c}\text { Change } \\
\text { (Day/Decade) }\end{array}$ & Significance Level & Test Statistic & Significance Level \\
\hline \multicolumn{5}{|l|}{ Poznan } \\
\hline $\operatorname{Tmin}<0{ }^{\circ} \mathrm{C}$ & -1.86 & $95.81 \%$ & -2.45 & $98.55 \%$ \\
\hline $\operatorname{Tmin}<-1{ }^{\circ} \mathrm{C}$ & -1.83 & $95.57 \%$ & -2.45 & $98.57 \%$ \\
\hline $\operatorname{Tmin}<-2{ }^{\circ} \mathrm{C}$ & -2.38 & $98.19 \%$ & -2.80 & $99.48 \%$ \\
\hline \multicolumn{5}{|l|}{ Kalisz } \\
\hline $\operatorname{Tmin}<0{ }^{\circ} \mathrm{C}$ & -2.91 & $99.96 \%$ & -3.54 & $99.95 \%$ \\
\hline $\operatorname{Tmin}<-1{ }^{\circ} \mathrm{C}$ & -3.51 & $99.94 \%$ & -3.38 & $99.92 \%$ \\
\hline $\operatorname{Tmin}<-2{ }^{\circ} \mathrm{C}$ & -2.46 & $96.11 \%$ & -2.12 & $96.59 \%$ \\
\hline \multicolumn{5}{|l|}{ Wielichowo } \\
\hline $\operatorname{Tmin}<0{ }^{\circ} \mathrm{C}$ & -1.53 & $81.20 \%$ & -1.49 & $86.47 \%$ \\
\hline $\operatorname{Tmin}<-1{ }^{\circ} \mathrm{C}$ & -0.87 & $60.89 \%$ & -0.87 & $61.81 \%$ \\
\hline $\operatorname{Tmin}<-2{ }^{\circ} \mathrm{C}$ & -0.89 & $59.53 \%$ & -0.73 & $53.71 \%$ \\
\hline \multicolumn{5}{|l|}{ Kielce } \\
\hline $\operatorname{Tmin}<0{ }^{\circ} \mathrm{C}$ & 0.28 & $21.95 \%$ & 0.40 & $31.24 \%$ \\
\hline $\operatorname{Tmin}<-1{ }^{\circ} \mathrm{C}$ & -0.19 & $15.25 \%$ & -0.26 & $20.15 \%$ \\
\hline $\operatorname{Tmin}<-2{ }^{\circ} \mathrm{C}$ & -1.61 & $94.29 \%$ & -2.33 & $97.99 \%$ \\
\hline \multicolumn{5}{|l|}{ Sandomierz } \\
\hline $\operatorname{Tmin}<0{ }^{\circ} \mathrm{C}$ & -2.66 & $99.77 \%$ & -3.07 & $99.78 \%$ \\
\hline $\operatorname{Tmin}<-1{ }^{\circ} \mathrm{C}$ & -2.36 & $99.50 \%$ & -2.79 & $99.47 \%$ \\
\hline $\operatorname{Tmin}<-2{ }^{\circ} \mathrm{C}$ & 0.78 & $55.3 \%$ & 0.64 & $47.68 \%$ \\
\hline \multicolumn{5}{|l|}{ Lublin } \\
\hline $\mathrm{Tmin}<0{ }^{\circ} \mathrm{C}$ & -1.73 & $95.50 \%$ & -1.94 & $95.18 \%$ \\
\hline $\operatorname{Tmin}<-1{ }^{\circ} \mathrm{C}$ & -2.68 & $99.55 \%$ & -2.90 & $99.62 \%$ \\
\hline $\operatorname{Tmin}<-2{ }^{\circ} \mathrm{C}$ & -1.45 & $85.16 \%$ & -1.51 & $86.98 \%$ \\
\hline
\end{tabular}

The numbers highlighted in bold show statistically significant results.

Distinctly different results were obtained when analyzing the dates of the last frosts in relation to the duration of the growing season (as the number of consecutive days in the growing season). Only for one station-Kalisz-for two temperature thresholds, an earlier occurrence of the last frosts event was observed (Table 2). Both the acceleration and the delay in the occurrence of the last spring frosts for various minimum temperature thresholds were recorded at the remaining stations. In addition, it is often that both accelerations and delays in the date of these frosts occur for one station, depending 
on the assumed temperature threshold. However, these changes are not statistically significant. The significance level of the Mann-Kendall test rarely exceeds 95\%, which allows to state that the date of the last frost during the growing season practically does not change.

Table 2. Trend characteristics of the last spring air frosts date in relation to the growing season (1961-2020).

\begin{tabular}{|c|c|c|c|c|}
\hline \multirow{2}{*}{ Station } & \multicolumn{2}{|c|}{ Linear Regression } & \multicolumn{2}{|c|}{ Mann-Kendall's Test } \\
\hline & $\begin{array}{c}\text { Change } \\
\text { (Day/Decade) }\end{array}$ & Significance Level & Test Statistic & Significance Level \\
\hline \multicolumn{5}{|l|}{ Poznan } \\
\hline $\operatorname{Tmin}<0{ }^{\circ} \mathrm{C}$ & 0.39 & $25.71 \%$ & 0.67 & $49.71 \%$ \\
\hline $\operatorname{Tmin}<-1^{\circ} \mathrm{C}$ & 0.41 & $26.67 \%$ & 0.68 & $50.53 \%$ \\
\hline $\operatorname{Tmin}<-2{ }^{\circ} \mathrm{C}$ & -0.46 & $32.32 \%$ & -0.34 & $27.10 \%$ \\
\hline \multicolumn{5}{|l|}{ Kalisz } \\
\hline $\operatorname{Tmin}<0{ }^{\circ} \mathrm{C}$ & -1.71 & $88.89 \%$ & -1.66 & $90.45 \%$ \\
\hline $\mathrm{Tmin}<-1^{\circ} \mathrm{C}$ & -2.19 & $94.82 \%$ & -2.31 & $97.90 \%$ \\
\hline $\operatorname{Tmin}<-2{ }^{\circ} \mathrm{C}$ & -1.71 & $91.60 \%$ & -1.97 & $95.80 \%$ \\
\hline \multicolumn{5}{|l|}{ Wielichowo } \\
\hline $\mathrm{Tmin}<0{ }^{\circ} \mathrm{C}$ & -0.88 & $50.19 \%$ & -0.70 & $51.74 \%$ \\
\hline $\operatorname{Tmin}<-1^{\circ} \mathrm{C}$ & -0.31 & $20.29 \%$ & -0.52 & $39.96 \%$ \\
\hline $\operatorname{Tmin}<-2{ }^{\circ} \mathrm{C}$ & -0.25 & $14.82 \%$ & -0.25 & $19.66 \%$ \\
\hline \multicolumn{5}{|l|}{ Kielce } \\
\hline $\operatorname{Tmin}<0{ }^{\circ} \mathrm{C}$ & 1.59 & $68.31 \%$ & 1.02 & $69.29 \%$ \\
\hline $\mathrm{Tmin}<-1^{\circ} \mathrm{C}$ & 1.12 & $50.62 \%$ & 0.82 & $59.20 \%$ \\
\hline $\operatorname{Tmin}<-2{ }^{\circ} \mathrm{C}$ & -0.95 & $59.52 \%$ & -0.90 & $62.97 \%$ \\
\hline \multicolumn{5}{|l|}{ Sandomierz } \\
\hline $\operatorname{Tmin}<0{ }^{\circ} \mathrm{C}$ & -0.85 & $55.78 \%$ & -1.05 & $70.56 \%$ \\
\hline $\operatorname{Tmin}<-1{ }^{\circ} \mathrm{C}$ & -0.68 & $44.14 \%$ & -0.95 & $65.94 \%$ \\
\hline $\mathrm{Tmin}<-2{ }^{\circ} \mathrm{C}$ & 0.81 & $60.93 \%$ & 0.88 & $62.15 \%$ \\
\hline \multicolumn{5}{|l|}{ Lublin } \\
\hline $\operatorname{Tmin}<0{ }^{\circ} \mathrm{C}$ & -0.26 & $17.97 \%$ & -0.41 & $31.73 \%$ \\
\hline $\mathrm{Tmin}<-1^{\circ} \mathrm{C}$ & -1.22 & $75.73 \%$ & -1.22 & $77.68 \%$ \\
\hline $\operatorname{Tm} \min <-2{ }^{\circ} \mathrm{C}$ & 0.11 & $11.48 \%$ & -0.25 & $19.58 \%$ \\
\hline
\end{tabular}

The numbers highlighted in bold show statistically significant results.

\subsubsection{Ground Frosts}

Detection of the trend in time series created on the basis of the minimum temperature at the ground level showed the existence of a strong trend for almost all analyzed time series, even at the level of $99 \%$, indicating the earlier date of the last spring frosts understood as a consecutive day of the year. The only statistically insignificant result for the Mann-Kendall test was obtained for the temperature threshold of $-2{ }^{\circ} \mathrm{C}$ at the Kalisz station (Table 3). At the remaining stations, a strong decreasing trend of about 2 to even 3.66 days per decade was observed, indicating an acceleration of the date of the last spring frosts. Mostly, it can be stated that the more severe frosts were analyzed, the more considerable was the change of date. 
Table 3. Trend characteristics of the last spring ground frosts date in relation to the calendar year (1961-2020).

\begin{tabular}{|c|c|c|c|c|}
\hline \multirow[b]{2}{*}{ Station } & \multicolumn{2}{|c|}{ Linear Regression } & \multicolumn{2}{|c|}{ Mann-Kendall's Test } \\
\hline & $\begin{array}{c}\text { Change } \\
\text { (Day/Decade) }\end{array}$ & Significance Level & Test Statistic & Significance Level \\
\hline \multicolumn{5}{|l|}{ Poznan } \\
\hline $\operatorname{Tmin}<0{ }^{\circ} \mathrm{C}$ & -2.61 & $97.28 \%$ & -2.23 & $97.45 \%$ \\
\hline $\operatorname{Tmin}<-2{ }^{\circ} \mathrm{C}$ & -2.31 & $96.99 \%$ & -2.06 & $96.70 \%$ \\
\hline $\operatorname{Tmin}<-4{ }^{\circ} \mathrm{C}$ & -3.06 & $99.91 \%$ & -3.64 & $99.97 \%$ \\
\hline \multicolumn{5}{|l|}{ Kalisz } \\
\hline $\operatorname{Tmin}<0{ }^{\circ} \mathrm{C}$ & -3.38 & $98.33 \%$ & -2.17 & $97.10 \%$ \\
\hline $\operatorname{Tmin}<-2{ }^{\circ} \mathrm{C}$ & -1.89 & $86.43 \%$ & -1.57 & $88.35 \%$ \\
\hline $\operatorname{Tmin}<-4^{\circ} \mathrm{C}$ & -2.73 & $94.50 \%$ & -1.96 & $95.10 \%$ \\
\hline \multicolumn{5}{|l|}{ Wielichowo } \\
\hline $\operatorname{Tmin}<0{ }^{\circ} \mathrm{C}$ & -1.86 & $95.81 \%$ & -2.45 & $98.55 \%$ \\
\hline $\operatorname{Tmin}<-2{ }^{\circ} \mathrm{C}$ & -2.39 & $98.19 \%$ & -2.80 & $99.48 \%$ \\
\hline $\operatorname{Tmin}<-4{ }^{\circ} \mathrm{C}$ & -2.81 & $98.68 \%$ & -2.53 & $98.87 \%$ \\
\hline \multicolumn{5}{|l|}{ Kielce } \\
\hline $\operatorname{Tmin}<0{ }^{\circ} \mathrm{C}$ & -2.35 & $96.48 \%$ & -2.04 & $95.87 \%$ \\
\hline $\operatorname{Tmin}<-2{ }^{\circ} \mathrm{C}$ & -2.66 & $97.40 \%$ & -2.11 & $96.55 \%$ \\
\hline $\operatorname{Tmin}<-4{ }^{\circ} \mathrm{C}$ & -3.00 & $99.57 \%$ & -3.02 & $99.75 \%$ \\
\hline \multicolumn{5}{|l|}{ Sandomierz } \\
\hline $\operatorname{Tmin}<0{ }^{\circ} \mathrm{C}$ & -3.32 & $99.78 \%$ & -2.94 & $99.66 \%$ \\
\hline $\operatorname{Tmin}<-2{ }^{\circ} \mathrm{C}$ & -3.18 & $99.83 \%$ & -3.08 & $95.50 \%$ \\
\hline $\operatorname{Tmin}<-4{ }^{\circ} \mathrm{C}$ & -3.66 & $99.71 \%$ & -2.79 & $99.79 \%$ \\
\hline \multicolumn{5}{|l|}{ Lublin } \\
\hline $\mathrm{Tmin}<0{ }^{\circ} \mathrm{C}$ & -1.86 & $95.81 \%$ & -2.45 & $98.55 \%$ \\
\hline $\operatorname{Tmin}<-2{ }^{\circ} \mathrm{C}$ & -2.39 & $98.19 \%$ & -2.80 & $99.48 \%$ \\
\hline $\operatorname{Tmin}<-4{ }^{\circ} \mathrm{C}$ & -2.81 & $98.68 \%$ & -2.53 & $98.87 \%$ \\
\hline
\end{tabular}

The numbers highlighted in bold show statistically significant results.

If the trends in the appearance of recent ground frosts in relation to the ongoing growing season are analyzed, the results are not as clear and unambiguous. It is true that there was a tendency indicating the earlier occurrence of the last spring frosts date for each of the stations and for each minimum temperature threshold, which ranged from -0.15 to -2.62 days per decade, but it was statistically significant only for the Wielichowo and Kielce stations and frosts exceeding $-4{ }^{\circ} \mathrm{C}$ (Table 4 ).

Table 4. Trend characteristics of the last spring ground frosts date in relation to the growing season (1961-2020).

\begin{tabular}{|c|c|c|c|c|}
\hline \multirow{2}{*}{ Station } & \multicolumn{2}{|c|}{ Linear Regression } & \multicolumn{2}{|c|}{ Mann-Kendall's Test } \\
\hline & $\begin{array}{c}\text { Change } \\
\text { (Day/Decade) }\end{array}$ & Significance Level & Test Statistic & Significance Level \\
\hline \multicolumn{5}{|l|}{ Poznan } \\
\hline $\operatorname{Tmin}<0{ }^{\circ} \mathrm{C}$ & -0.46 & $24.20 \%$ & -0.15 & $12.17 \%$ \\
\hline $\operatorname{Tmin}<-2{ }^{\circ} \mathrm{C}$ & -0.15 & $8.68 \%$ & -0.05 & $4.70 \%$ \\
\hline $\operatorname{Tmin}<-4{ }^{\circ} \mathrm{C}$ & -0.81 & $52.3 \%$ & -0.71 & $52.14 \%$ \\
\hline \multicolumn{5}{|l|}{ Kalisz } \\
\hline $\operatorname{Tmin}<0^{\circ} \mathrm{C}$ & -2.62 & $87.40 \%$ & -1.21 & $77.21 \%$ \\
\hline $\operatorname{Tmin}<-2{ }^{\circ} \mathrm{C}$ & -0.99 & $47.89 \%$ & -1.16 & $75.21 \%$ \\
\hline $\operatorname{Tmin}<-4^{\circ} \mathrm{C}$ & -1.93 & $81.72 \%$ & -1.64 & $89.91 \%$ \\
\hline
\end{tabular}


Table 4. Cont.

\begin{tabular}{|c|c|c|c|c|}
\hline \multirow{2}{*}{ Station } & \multicolumn{2}{|c|}{ Linear Regression } & \multicolumn{2}{|c|}{ Mann-Kendall's Test } \\
\hline & $\begin{array}{c}\text { Change } \\
\text { (Day/Decade) }\end{array}$ & Significance Level & Test Statistic & Significance Level \\
\hline \multicolumn{5}{|l|}{ Wielichowo } \\
\hline $\operatorname{Tmin}<0{ }^{\circ} \mathrm{C}$ & -1.08 & $95.00 \%$ & -0.75 & $54.87 \%$ \\
\hline $\operatorname{Tmin}<-2{ }^{\circ} \mathrm{C}$ & -1.90 & $70.69 \%$ & -1.78 & $92.49 \%$ \\
\hline $\operatorname{Tmin}<-4{ }^{\circ} \mathrm{C}$ & -1.99 & $77.86 \%$ & -2.11 & $96.50 \%$ \\
\hline \multicolumn{5}{|l|}{ Kielce } \\
\hline $\operatorname{Tmin}<0{ }^{\circ} \mathrm{C}$ & -1.59 & $70.69 \%$ & -0.74 & $54.12 \%$ \\
\hline $\operatorname{Tmin}<-2{ }^{\circ} \mathrm{C}$ & -1.90 & $77.86 \%$ & -1.13 & $74.27 \%$ \\
\hline $\operatorname{Tmin}<-4{ }^{\circ} \mathrm{C}$ & -2.20 & $88.90 \%$ & -2.23 & $97.39 \%$ \\
\hline \multicolumn{5}{|l|}{ Sandomierz } \\
\hline $\operatorname{Tmin}<0{ }^{\circ} \mathrm{C}$ & -1.58 & $73.22 \%$ & -0.75 & $54.86 \%$ \\
\hline $\operatorname{Tmin}<-2{ }^{\circ} \mathrm{C}$ & -1.44 & $74.45 \%$ & -1.46 & $85.64 \%$ \\
\hline $\operatorname{Tmin}<-4{ }^{\circ} \mathrm{C}$ & -1.87 & $91.77 \%$ & -1.93 & $94.69 \%$ \\
\hline \multicolumn{5}{|l|}{ Lublin } \\
\hline $\operatorname{Tmin}<0^{\circ} \mathrm{C}$ & -0.30 & $20.41 \%$ & -0.26 & $20.64 \%$ \\
\hline $\operatorname{Tmin}<-2{ }^{\circ} \mathrm{C}$ & -1.37 & $82.96 \%$ & -1.41 & $84.24 \%$ \\
\hline $\operatorname{Tmin}<-4{ }^{\circ} \mathrm{C}$ & -1.24 & $81.80 \%$ & -1.77 & $92.39 \%$ \\
\hline
\end{tabular}

The numbers highlighted in bold show statistically significant results.

\subsection{Changes in the Probability of Late Spring Frosts Occurrence}

\subsubsection{Air Frosts}

In both analyzed regions, the probability of the last spring frost at the height of $2 \mathrm{~m}$ (as a consecutive day of the year) differed very clearly for individual stations. In both regions, there were stations (Sandomierz and Kalisz) for which the 95\% probability that there would be no frost was recorded around the 130th day of the year (10 May). There were also stations (Kielce and Wielichowo) for which this probability value was observed around the 150th day of the year, i.e., on 30 May, so almost 3 weeks later. Figures 3-7 show a comparison of the course of the probability of the last spring frost event for different stations and different minimum temperature thresholds.

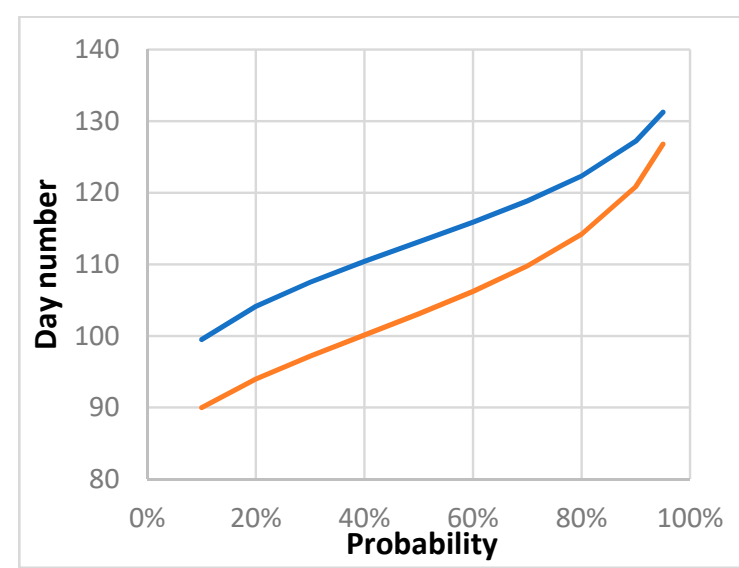

(a)

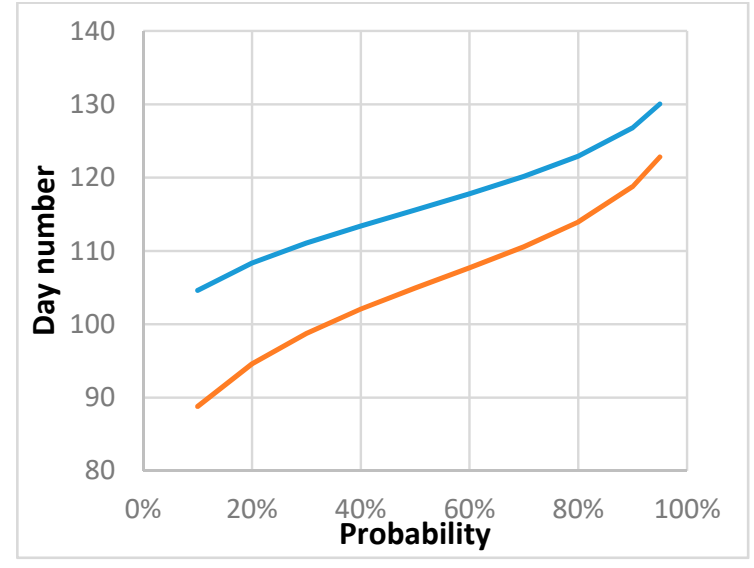

(b)

Figure 3. The probability curves of the last spring frost event described by a calendar day number (Tmin $<0{ }^{\circ} \mathrm{C}$ ) in the period of 1961-1990 (blue line) and 1991-2020 (orange line). (a) Sandomierz (b) Kalisz. 


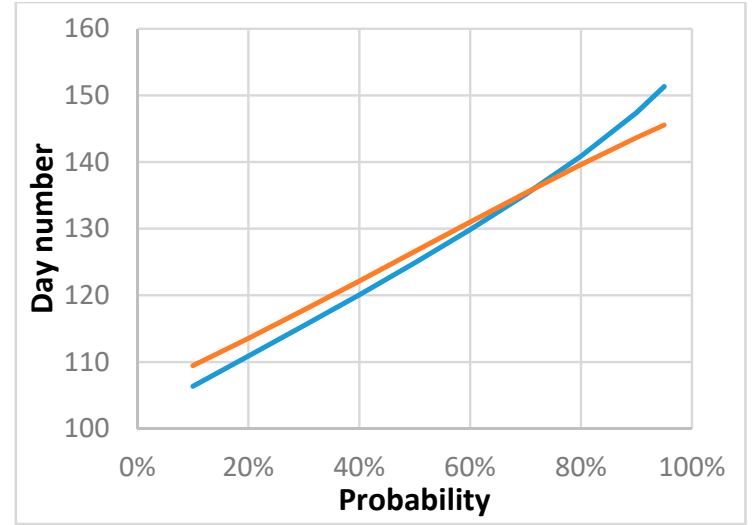

(a)

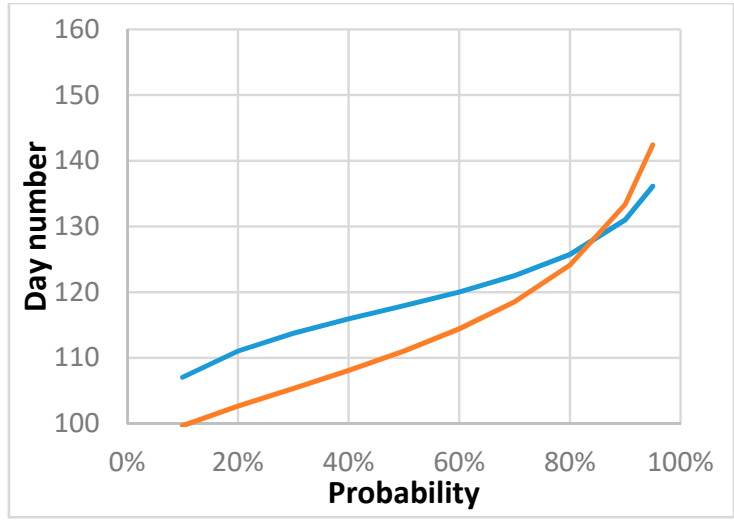

(b)

Figure 4. The probability curves of the last spring frost event described by a calendar day number (Tmin $<0{ }^{\circ} \mathrm{C}$ ) in the period of 1961-1990 (blue line) and 1991-2020 (orange line). (a) Kielce (b) Poznan.

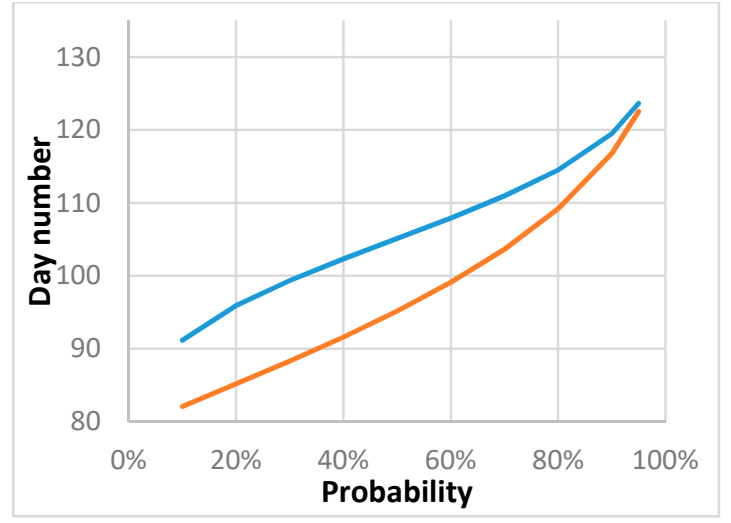

(a)

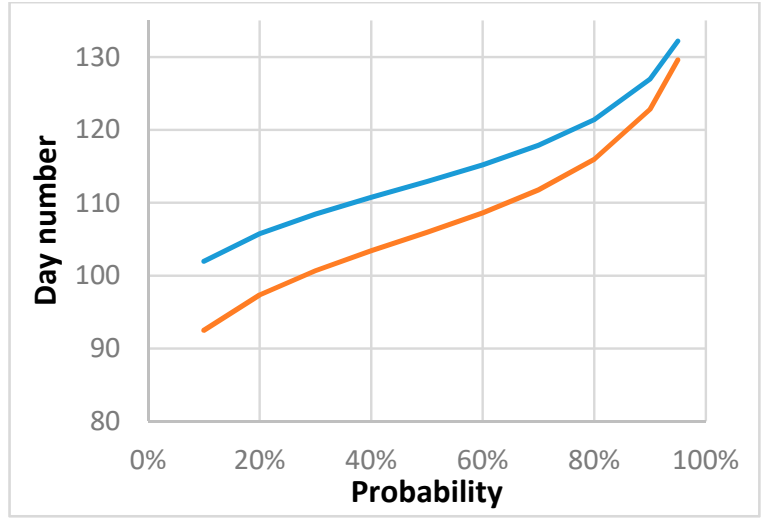

(b)

Figure 5. The probability curves of the last spring frost event described by a calendar day number (Tmin $<-1{ }^{\circ} \mathrm{C}$ ) in the period of 1961-1990 (blue line) and 1991-2020 (orange line). (a) Sandomierz (b) Poznan.

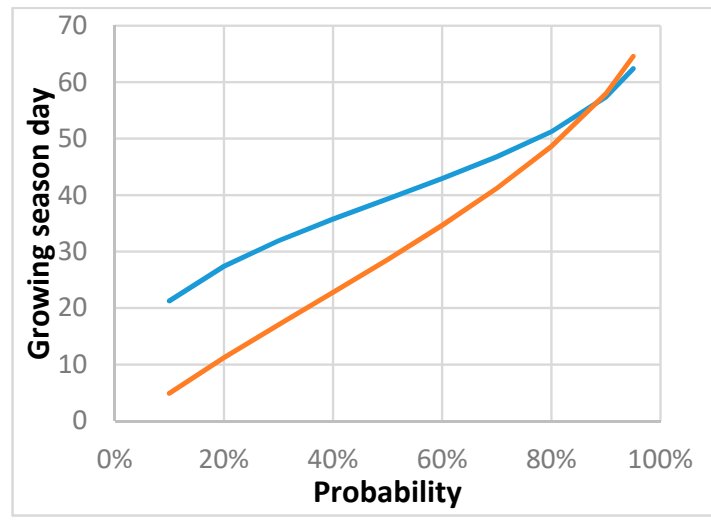

(a)

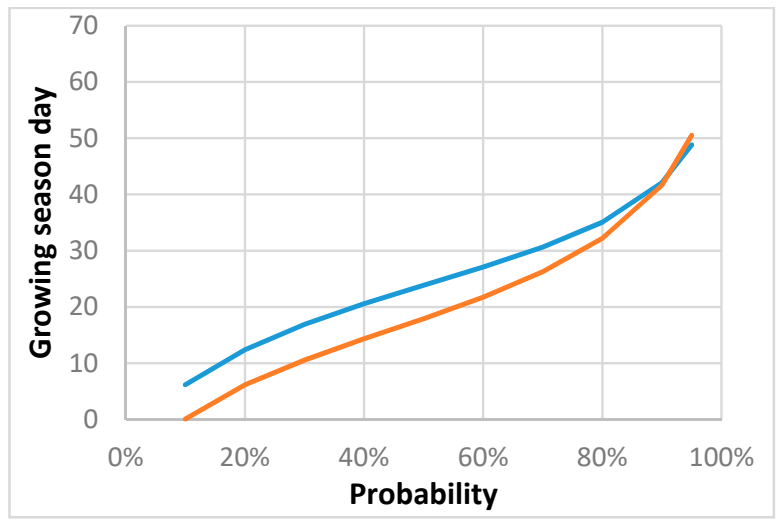

(b)

Figure 6. The probability curves of the last spring frost event described by a day number in the growing season (Tmin $<0{ }^{\circ} \mathrm{C}$ ) in the period of 1961-1990 (blue line) and 1991-2020 (orange line). (a) Wielichowo (b) Kielce. 


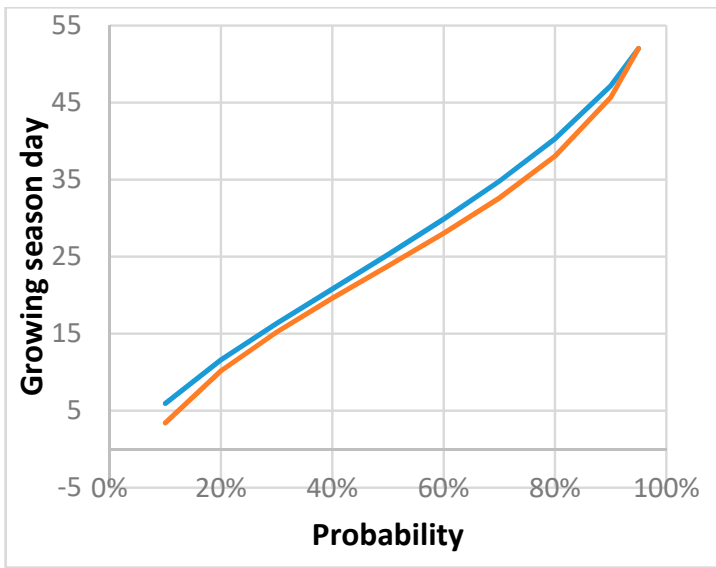

(a)

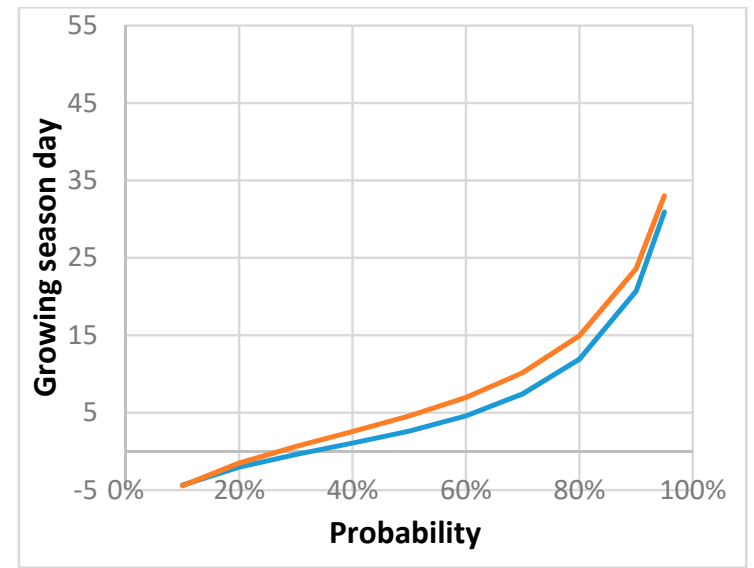

(b)

Figure 7. The probability curves of the last spring frost described by a day number in the growing season in the period of 1961-1990 (blue line) and 1991-2020 (orange line). (a) Poznan for Tmin $<0{ }^{\circ} \mathrm{C}$, (b) Sandomierz for Tmin $<-2{ }^{\circ} \mathrm{C}$.

At most stations, for the $0{ }^{\circ} \mathrm{C}$ temperature threshold, frosts ended earlier in the years 1991-2020 for the entire probability range. The probability curves for the two periods generally ran almost parallel, getting slightly closer together for the higher probability levels. In the years 1961-1990, frosts for some probability levels occurred even 10-15 days later compared to the period 1991-2020 (Figure 3a,b).

There were also some deviations from this course, e.g., for the Kielce station (Figure 4a), they ran very close to each other, intersecting around the probability of $70 \%$. At the Poznan station (Figure $4 \mathrm{~b}$ ), for the lower probability values, in the years 1961-1990, the last frost appeared 6-7 days later, and for a probability level of $95 \%$, it occurred 5 days earlier.

Furthermore, for the lower temperature thresholds $\left(-1{ }^{\circ} \mathrm{C}\right.$ and $\left.-2{ }^{\circ} \mathrm{C}\right)$, spring frosts in the whole range of probability most often occurred later in the years 1961-1990. However, the courses of the curves were no longer parallel, and for the higher probability values of 90 and 95\%, the curves approached each other (Figure 5a,b), which means that the last frosts occurring at very late dates practically did not change.

The comparison of the analyzed periods, when the date of the last spring frost is defined as the consecutive day of the growing season, did not show such a clear acceleration of the date of the last frosts, especially for the probability levels above $90 \%$. Moreover, for the temperature threshold of $0{ }^{\circ} \mathrm{C}$, the probability curves approached each other around the day corresponding to the $80 \%$ probability and crossed on the day corresponding to the $90 \%$ probability (Figure $6 \mathrm{a}, \mathrm{b}$ ). This means that the late frost, recurring on average every 5 or 10 years, occurred just as often or even more often in the warmer period of 1991-2020.

As for lower temperature thresholds, the courses of the probability curves for both periods are very similar, and the last frost occurred in the period 1991-2020, both earlier and later than in the period 1961-1990 (Figure 7a,b).

\subsubsection{Ground Frosts}

Extremely late frosts (with $95 \%$ probability) near the ground, depending on the station, may occur from about 3 weeks (in Kalisz) to almost 5 weeks later (in Poznan) than those measured at the height of $2 \mathrm{~m}$. This means that once every 20 years, ground frosts may appear in early or even mid-June. 
For minimum temperature below $0{ }^{\circ} \mathrm{C}$, the date of the last frost (as the consecutive day of the year) occurred much faster in the entire probability range in the period 1991-2020 for four out of six stations. In Poznan, $80 \%$ (Figure 8a) probability that a frost will no longer occur was observed in the years 1991-2020 on the 145th day of the year, while in the years 1961-1990, it was the 153rd day. Even more considerable differences were recorded in Kalisz (Figure $8 \mathbf{b}$ ), and for this probability value, it was the 139th and 152nd day in a year, respectively.

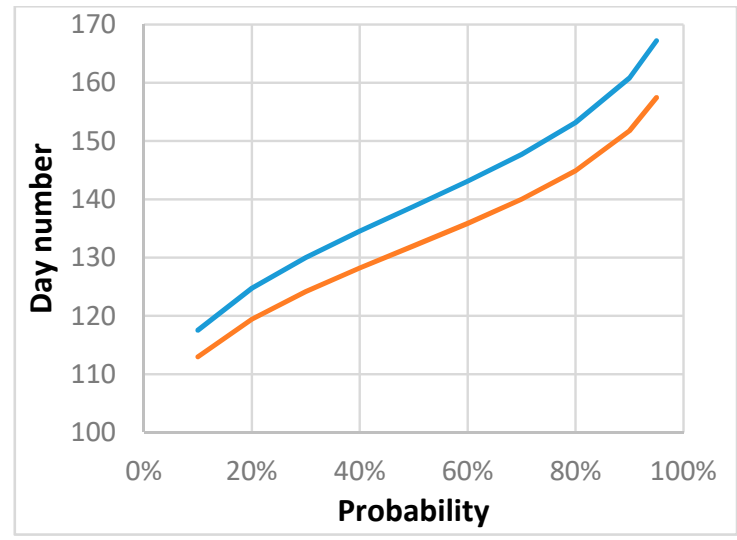

(a)

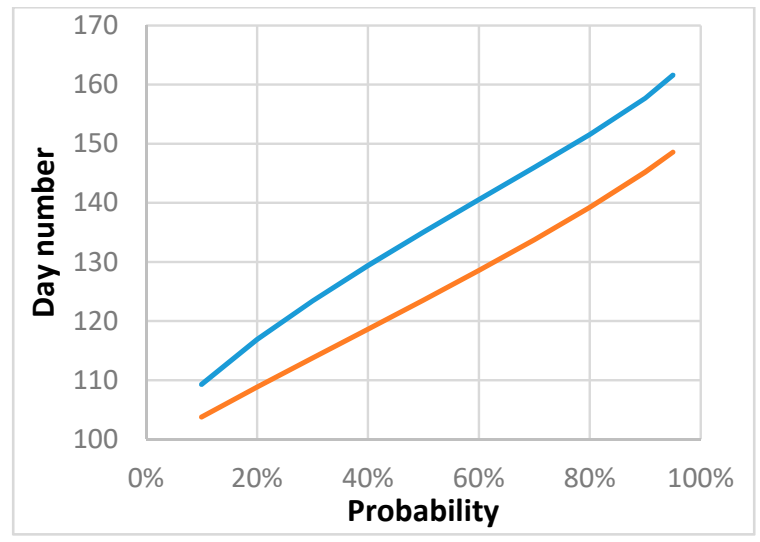

(b)

Figure 8. The probability curves of the last spring frost event described by a calendar day number (Tmin $<0{ }^{\circ} \mathrm{C}$ ) in the period of 1961-1990 (blue line) and 1991-2020 (orange line). (a) Poznan, (b) Kalisz.

For 2 stations-Wielichowo (Figure 9a) and Lublin (Figure 9b)-around the day, which ended the frost period with $80 \%$ probability, the probability curves intersected, and so for the later date of the last frost, the probability was higher in 1991-2020.

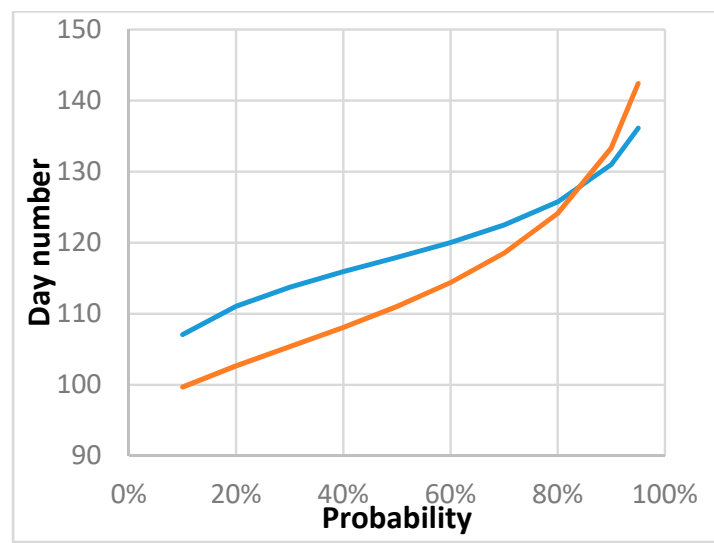

(a)

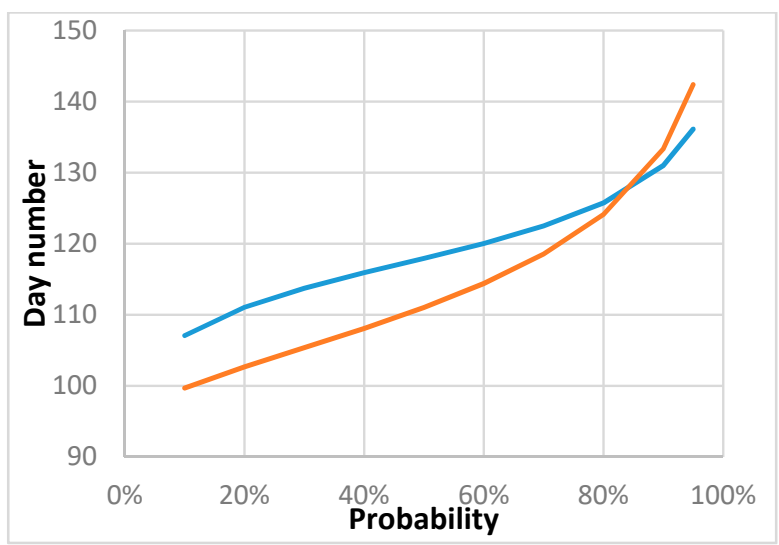

(b)

Figure 9. The probability curves of the last spring frost described by a calendar day number $\left(\operatorname{Tmin}<0{ }^{\circ} \mathrm{C}\right)$ in the period of 1961-1990 (blue line) and 1991-2020 (orange line). (a) Wielichowo, (b) Lublin.

In almost every case, the probabilities of the last spring frosts for the thresholds $\operatorname{Tmin}<-2{ }^{\circ} \mathrm{C}$ and Tmin $<-4{ }^{\circ} \mathrm{C}$ differed very clearly for both analyzed periods. Hence, at Wielichowo (Figure 10a) and Lublin (Figure 10b) stations, the $90 \%$ probability of a ground frost $\mathrm{Tmin}<-2{ }^{\circ} \mathrm{C}$ occurred 9 days earlier in the period 1991-2020. 


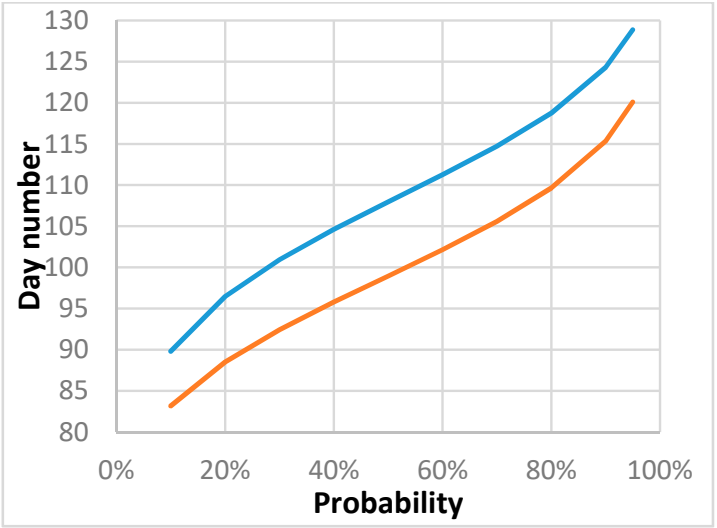

(a)

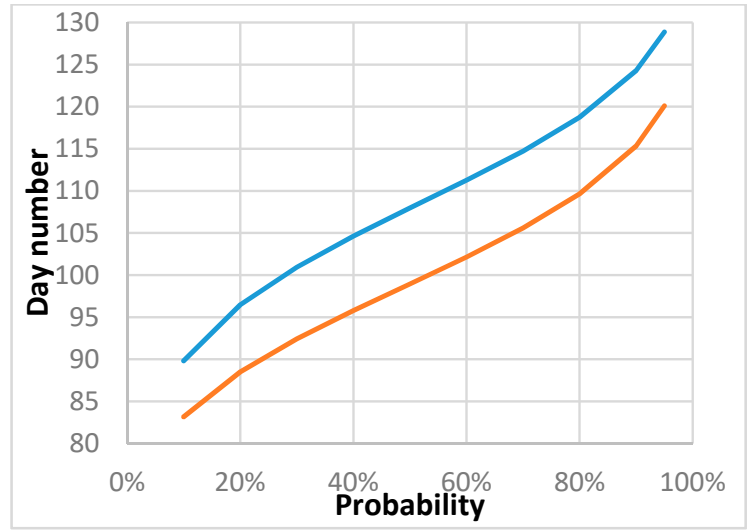

(b)

Figure 10. The probability curves of the last spring frost event described by a calendar day number in the period of 1961-1990 (blue line) and 1991-2020 (orange line). (a) Wielichowo with Tmin $<-2{ }^{\circ} \mathrm{C}$,

(b) Lublin Tmin $<-4{ }^{\circ} \mathrm{C}$.

The comparison of the analyzed periods, 1961-1990 and 1990-2020, when the date of the last spring frost is defined as the consecutive day of the growing season, resulted in a very different course of the probability curves for individual stations and different temperature thresholds.

For the lowest considered temperature threshold near the ground, Tmin $<-4{ }^{\circ} \mathrm{C}$, for almost all stations, there was a very strong acceleration of the last frost date. The course of the probability curves is quite similar at all stations. However, the differences between the periods are the greatest in Wielichowo-11 days for a 90\% probability (Figure 11a) and in Sandomierz-12 days (Figure 11b).

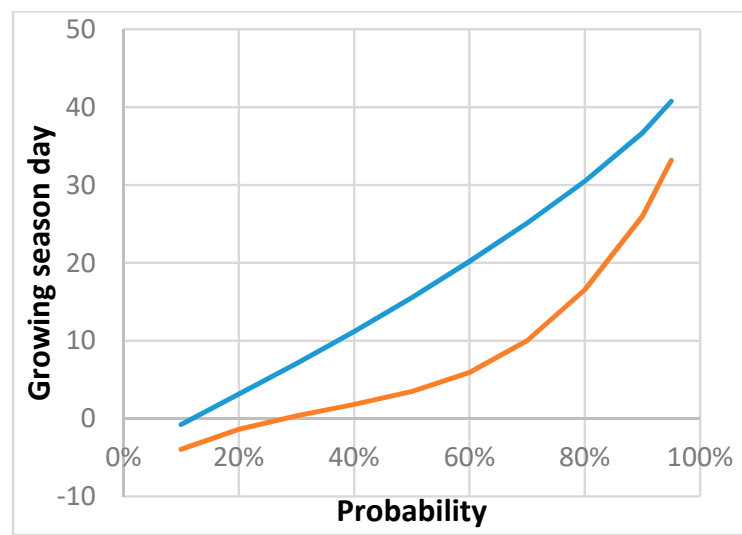

(a)

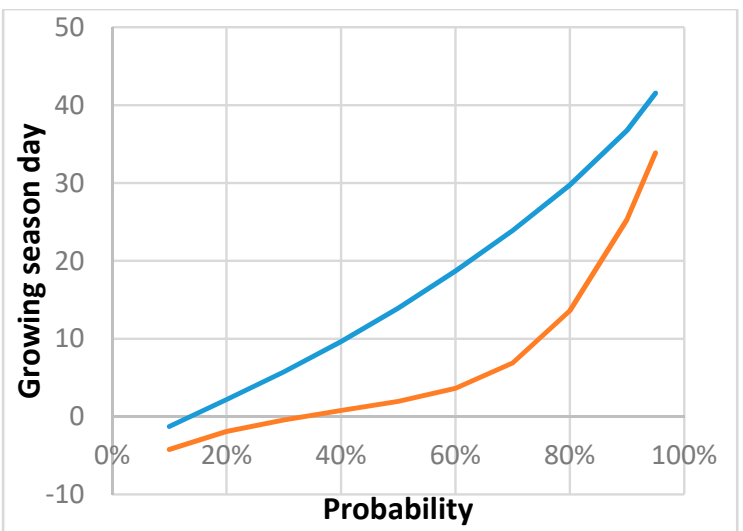

(b)

Figure 11. The probability curves of the last spring frost event described by a day number in the growing season ( $\operatorname{Tmin}<-4{ }^{\circ} \mathrm{C}$ ) in the period of 1961-1990 (blue line) and 1991-2020 (orange line). (a) Wielichowo, (b) Sandomierz.

\section{Discussion}

For most stations, the analysis of trends in the time series of the last spring frost date at the height of $2 \mathrm{~m}$ showed a statistically significant trend indicating its earlier appearance. The trend calculated in this research study, ranging from 1.6 to 3.5 days per decade, and statistically significant changes confirm the previous results of research studies from the territory of Poland [7,23]. Any minor differences may result from the selection of the station or the analyzed period. 
Of course, Poland is not the only country in which such observations have been made. In the literature, one can find a number of studies, not only from Europe [14] but also from other continents, such as North America [24] or Asia [25], which show a statistically significant shift of the date of the last spring frost.

Despite this, in the last 10 years, in Europe, in at least the last 2 spring seasons (2011 and 2017), very large losses related to the occurrence of late and severe frosts were recorded. The acceleration of the last spring frost date calculated as the number of a consecutive day of the year does not seem to have a significant impact on reducing losses in agriculture and horticulture. In May 2011, significant losses in horticultural crops with a decrease in yields exceeding even $70 \%$ in many regions of Poland [26] were recorded. In 2017, the April and May strong frosts in Europe resulted in unprecedented losses of over euros 3.3 billion [27] in grapevines and fruit trees. One of the reasons for that may have been the change in the length of the growing season, including its earlier beginning.

Therefore, to correctly assess the changes in the risk associated with the occurrence of late frosts, they should be related to parameters that will allow to associate them with the plant's development phase, e.g., growing degree days for different temperature levels or the day of frost occurrence calculated as a consecutive day of the growing season. In this study, referencing the last spring frost date to the beginning of the growing season resulted in considerable changes in the results of trend detection. While changes in the date of the last frosts, described as a day in a calendar year, undoubtedly take place, they practically do not change in relation to the growing season. Statistically significant changes during the growing season concerned only 1 station for measurements at the height of $2 \mathrm{~m}$ and 2 for measurements at the ground level.

According to [28], it is possible that the extension of the growing season duration, despite the decrease in the number of frost days per year, will increase the risk for plants. Moreover, the increase in the number of days with frost during the growing season is the most significant in regions where the growing season has lengthened the most, including Europe. In paper [29], the date of occurrence of heavy spring frosts (Tmin $<-4{ }^{\circ} \mathrm{C}$ ) was compared to Growing Degree Days at $5{ }^{\circ} \mathrm{C}$. The obtained results show great spatial variability. In large areas of Europe and Asia, where the increase in the average annual air temperature is the highest, the risk of damage caused by late frosts increases.

No changes in the probability of crop losses or even an increase in this probability could be even more pronounced if they were related to the key stages of development of specific plant species. Such results were presented for 27 tree species in Europe [30].

It should also be remembered that the risk of crop losses caused by spring frosts may be different for different species and also for different populations within species depending on geographic location.

\section{Conclusions}

Both for the temperature measurements at the height of $2 \mathrm{~m}$ and $0.05 \mathrm{~m}$ above the ground level, regardless of the analyzed temperature threshold, a clear and statistically significant trend indicating an earlier occurrence of the last spring frost is most often observed. Such a shift is also reported by other researchers, e.g., $[17,31]$. However, this does not reduce the risk of losses in agriculture and horticulture-related to the occurrence of late and strong frosts.

Defining the last frost date as a consecutive day of the growing season significantly reduces the number of time series with statistically significant trends indicating the acceleration of the last spring frost. For frosts at the height of $2 \mathrm{~m}$, the results, depending on the station and the analyzed temperature level, indicate both its forward and backward shifts.

The comparison of the periods 1961-1990 and 1991-2020 showed that for the probability ranges indicating a relatively quick appearance of the last frost (typical spring frosts), it almost always appears significantly later in the period 1961-1990. For higher probability ranges, where the last frost occurs extremely late, with a probability of once every 5 or 10 years, it is very often that there are no big differences between the periods, and it even happened that in the period 1991-2020, the frost occurred later. 
Hence, to conclude, in spite of earlier spring phenology due to climate warming, results suggest that the risk of damaging frost events to vegetation has remained almost unchanged. Such a statement is in line with other research studies, e.g., [32]. It seems that in order to better assess the risk of losses related to the occurrence of exceptional late and/or strong frosts, the date of their last occurrence should be referenced to either the day of the growing season or specific ranges of GDD sums at which plants are particularly sensitive to frost damage.

Author Contributions: D.G. and M.S. designed the research and interpreted the results together, except for methodology and software-only D.G. In detail: Conceptualization, D.G. and M.S.; methodology, D.G.; software, D.G.; validation, D.G. and M.S.; formal analysis, D.G. and M.S.; investigation, D.G. and M.S.; resources, D.G. and M.S.; data curation, D.G.; writing — original draft preparation, D.G and M.S.; writing—review and editing, D.G. and M.S; visualization, D.G. and M.S. All authors have read and agreed to the published version of the manuscript.

Funding: This research received no external funding.

Conflicts of Interest: The authors declare no conflict of interest.

\section{References}

1. Demidowicz, G.; Doroszewski, A.; Górski, T. Wstępna ocena zagrożenia przymrozkowego roślin sadowniczych. Folia Univ. Agric. Stetin. Agric. 1999, 79, 57-60.

2. Koźmiński, C.; Michalska, B. Niekorzystne zjawiska atmosferyczne w Polsce. Straty w rolnictwie. In Klimatyczne Zagrożenia Rolnictwa w Polsc; Koźmiński, C., Michalska, B., Leśny, J., Eds.; Uniwersytet Szczeciński: Szczecin, Poland, 2010; pp. 9-54.

3. Kalbarczyk, R. Spatial and temporal variability of the occurrence of ground frost in Poland and its effect on growth, development and yield of pickling cucumber (Cucumis sativus L.), 1966-2005. Acta Sci. Pol. Hortorum Cultus 2002, 9, 3-26.

4. Bartoszek, K.; Skiba, K.; Dobek, M.; Siłuch, M.; Wereski, S. Frost occurrence in April and May in the eastern Poland area in the period 1988-2007. Acta Geoph. 2010, 6, 24-33.

5. Kołodziej, J.; Wegrzyn, A. Czasowy i przestrzenny rozkład przymrozków na Lubelszczyźnie 1971-90). I. Przymrozki na wysokości 200 cm nad powierzchnia gruntu. Annales UMCS Sec. E 2000, 55, 205-226.

6. Kołodziej, J.; Wegrzyn, A. Czasowy i przestrzenny rozkład przymrozków na Lubelszczyźnie (1971-90). II. Przymrozki na wysokości $5 \mathrm{~cm}$ nad powierzchnia gruntu. Annales UMCS Sec. E 2000, 55, 227-246.

7. Tomczyk, A.M.; Szyga-Pluta, K.; Majkowska, A. Frost and frost-free periods in Poland and neighbouring countries. Open Geosci. 2015, 7, 812-823. [CrossRef]

8. $\quad$ Easterling, D.R.; Horton, B.; Jones, P.D.; Peterson, T.C.; Karl, T.R.; Parker, D.E.; Salinger, M.J.; Razuvayev, V.; Plummer, N.; Jamason, P.; et al. Maximum and minimum temperature trends for the globe. Science 1997, 277, 364-367. [CrossRef]

9. Hansen, J.; Sato, M.; Ruedy, R. Long-term changes of the diurnal temperature cycle: Implications about mechanisms of global climate change. Atmos. Res. 1995, 37, 175-209. [CrossRef]

10. Matiu, M.; Ankerst, D.P.; Menzel, A. Asymmetric trends in seasonal temperature variability in instrumental records from ten stations in Switzerland, Germany and the UK from 1864 to 2012. Int. J. Climatol. 2016, 36, 13-27. [CrossRef]

11. Fu, Y.H.; Piao, S.; Op de Beeck, M.; Cong, N.; Zhao, H.; Zhang, Y.; Menzel, A.; Janssens, I.A. Recent spring phenology shifts in western Central Europe based on multiscale observations. Glob. Ecol. Biogeogr. 2014, 23, 1255-1263. [CrossRef]

12. Chmielewski, F.M.; Rotzer, T. Annual and spatial variability of the beginning of growing season in Europe in relation to air temperature changes. Clim. Res. 2002, 19, 257-264. [CrossRef]

13. Menzel, A.; Gert, J.; Rein, A.; Helfried, S.; Nicole, E. Variations of the climatological growing season (1951-2000) in Germany compared with other countries. Int. J. Clim. 2003, 23, 793-812. [CrossRef]

14. Scheifinger, H.; Menzel, A.; Koch, E.; Peter, C.H. Trends of spring time frost events and phenological dates in Central Europe. Theor. Appl. Clim. 2003, 74, 41-51. [CrossRef]

15. Lhotka, O.; Brönnimann, S. Possible Increase of Vegetation Exposure to Spring Frost under Climate Change in Switzerland. Atmosphere 2020, 11, 391. [CrossRef]

16. WMO. Protection against Frost Damage; WMO-No. 133; WMO: Geneva, Switzerland, 1963. 
17. Dragańska, E.; Rynkiewicz, I.; Panfil, M. Częstotliwość i intensywność występowania przymrozków w Polsce Północno-Wschodniej w latach 1971-2000. Acta Agrophysica 2004, 3, 35-41.

18. Gumiński, R. Próba wydzielenia dzielnic rolniczo-klimatycznych w Polsce. Przegl. Meteorol. Hydrol. 1948, 1, 7-20.

19. Huculak, W.; Makowiec, M. Wyznaczanie meteorologicznego okresu wegetacyjnego na podstawie jednorocznych materiałów obserwacyjnych. Zesz. Nauk. SGGW 1977, 25, 65-72.

20. Klein Tank, A.M.G. Daily dataset of 20thcentury surface air temperature and precipitation series for the European Climate Assessment. Int. J. Climatol. 2002, 22, 1441-1453. [CrossRef]

21. Radziejewski, M.; Kundzewicz, Z.W. Hydrospect, Version 2.0., 2004 User's Manual. Available online: https://library.wmo.int/doc_num.php?explnum_id=9282 (accessed on 20 August 2020).

22. Boessenkool, B. Extremestat: Quantile Estimation. 2017. Available online: https://cran.r-project.org/web/ packages/xtremeStat/vignettes/extremeStat.html (accessed on 10 August 2020).

23. Bielec-Bąkowska, Z.; Piotrowicz, K.; Krępa-Adolf, E. Trends in the frost-free season with parallel circulation and air mass statistics in Poland. Idöjárás 2018, 122, 375-392. [CrossRef]

24. McCabe, G.J.; Betancourt, J.L.; Feng, S. Variability in the start, end, and length of frost-free periods across the conterminous United States during the past century. Int. J. Climatol. 2015, 35, 4673-4680. [CrossRef]

25. Zhang, D.; Xu, W.; Li, J.; Cai, Z.; An, D. Frost-free season lengthening and its potential cause in the Tibetan Plateau from 1960 to 2010. Theory Appl. Climatol. 2014, 115, 441-450. [CrossRef]

26. Doroszewski, A.; Wróblewska, E.; Józwicki, T.; Mizak, K. Ocena szkód w roslina sadowniczych i ogrodniczych powodowanych przez przymrozki w maju 2011 roku (Evaluation of damage to fruit and horticultural plants caused by frosts in May 2011). Theory Appl. Climatol. 2015, 115, 441-450.

27. Faust, E.; Herbold, J. Spring Frost Losses and Climate Change-Not a Contradiction in Terms; Munich RE: Munich, Germany, 2018.

28. Liu, Q.; Piao, S.; Janssens, I.A.; Fu, Y.H.; Peng, S.; Lian, X.; Ciais, P.; Myneni, R.B.; Peñuelas, J.; Wang, T.V. Extension of the growing season increases vegetation exposure to frost. Nat. Commun. 2018, 9, 429. [CrossRef] [PubMed]

29. Zohner, C.M.; Mo, L.; Renner, S.S.; Svenning, J.-C.; Vitasse, Y.; Benito, B.M.; Ordonez, A.; Baumgarten, F.; Bastin, J.-F.; Sebald, V.; et al. Late-spring frost risk between 1959 and 2017 decreased in North America but increased in Europe and Asia. Proc. Natl. Acad. Sci. USA 2020, 117, 12192-12200. [CrossRef] [PubMed]

30. Ma, Q.; Huang, J.G.; Hanninen, H.; Berninger, F. Divergent trends in the risk of spring frost damage to trees in Europe with recent warming. Glob. Chang. Biol. 2019, 25, 351-360. [CrossRef] [PubMed]

31. Potop, V.; Zahradníček, P.; Türkott, L.; Štěpánek, P.; Soukup, J. Potential impacts of climate change on damaging frost during growing season of vegetables. Sci. Agric. Bohem. 2014, 45, 26-35. [CrossRef]

32. Vitasse, Y.; Rebetez, M. Unprecedented risk of spring frost damage in Switzerland and Germany in 2017. Clim. Chang. 2018, 149, 233-246. [CrossRef]

Publisher's Note: MDPI stays neutral with regard to jurisdictional claims in published maps and institutional affiliations.

(C) 2020 by the authors. Licensee MDPI, Basel, Switzerland. This article is an open access article distributed under the terms and conditions of the Creative Commons Attribution (CC BY) license (http://creativecommons.org/licenses/by/4.0/). 